\title{
GROUND WATER RECHARGE TECHNIQUES IN INDIA
}

\section{KUMOD RANJAN JHA ${ }^{1 *}$, GAURAV KUMAR ${ }^{2}$, KANISHK GAUR ${ }^{3}$, DINESH KUMAR ${ }^{4}$, OJESVI BHARDWAJ ${ }^{5}$}

*Corresponding Author: -

\section{OUTLINE}

1. Introduction

2 Ground water in India.

3. Damage to ground water recharge system.

4. Artificial recharge.

5. Recharge techniques.

6. Conclusions.

7. References.

\begin{abstract}
: -
This paper is an Enquiry into the modern day techniques for recharging ground water, which are currently being employed in India. This paper also discusses some possible improvements in the current order of things.as we know the ground water is a crucial factor for any nation and for a country like India, where the population is increasing day by day this topic is of paramount importance. This paper gives sufficient material for a thorough overview of the issue
\end{abstract}

Keywords: ground water importance, damage, recharge techniques.

\section{(c) $(\$)$}




\section{INTRODUCTION}

Groundwater is part of the Earth's water or hydrological cycle. When rain falls, a part infiltrates the soil and the remainder evaporates or runs off into rivers. The roots of plants will take up a proportion Of this moisture and then lose it through transpiration to the atmosphere, but some will infiltrate more Deeply, eventually accumulating above an impermeable bed, saturating available pore space and Forming an underground reservoir. Underground strata that can both store and transmit accumulated Groundwater to outlets in rivers, springs and the sea are termed aquifers. Recharge of ground is very crucial as it ensures that the minimum level of ground water, which we are going to discuss in this paper.

\section{GROUNDWATER IN INDIA}

For almost all the water needs of the country, groundwater is by far the most important water resource. Worldwide, according to a UNEP study (Groundwater its susceptibility to degradation, 2003), Over 2 Billion people depend on aquifers for their drinking water. 40 per cent of the world's food is produced by irrigated agriculture that relies largely on groundwater. Groundwater constitutes about 95 per cent of the freshwater on our planet (discounting that locked in the polar ice caps), making it fundamental to human life and economic development. According to the report of the National Commission on Integrated Water Resources Development (GOI Sept 1999), the total replenish able ground water is estimated as $432 \mathrm{BCM}$. Out of this, $396 \mathrm{BCM}$ is considered utilizable - $71 \mathrm{BCM}(15 \%)$ for domestic, industrial and other uses and $325 \mathrm{BCM}(90 \%$ of the balance) for irrigation.

\section{DAMAGE TO GROUNDWATER RECHARGE SYSTEM}

Direct human interventions over the years have led to reduction in groundwater recharge. These include: deforestation, destruction of local water systems (including traditional water systems) (like ponds, tanks, lakes, wetlands and so on), stoppage of river flows by dams and even run of the river projects. Deforestation also leads to change in river flow regime in the affected area that also affects the recharge in the given area. There are larger and indirect human interventions that has also affected the groundwater recharge systems, including urbanization, concretization of more and more land, the those factors that lead to global warming also contribute in reduction in groundwater levels as vapor-transpiration needs are higher when temperatures go up, leading to more groundwater use. Mining also leads to destruction of groundwater recharge systems in the mined areas. In fact in mining areas groundwater is many times unnecessarily pumped out so that mining becomes possible. This could be minimized and restored at least when mining in a given area is completed,

But that almost never happens. There are some human interventions that also seemingly add to natural groundwater recharging.

\section{ARTIFICIAL RECHARGE}

*Recharging practices began in 19th century in Europe.

*Traditional water harvesting in India dates back to Indus Valley Civilization and Mughal Period.

*The artificial recharge is the augmentation of underground aquifers by some methods of construction by artificially changing the natural conditions.

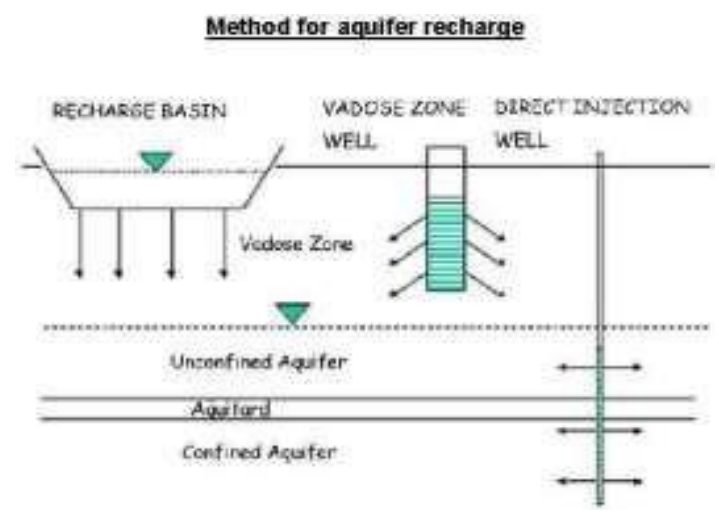

\section{RECHARGE TECHNIQUES \\ Basin Spreading Recharge}

Water is recharged by releasing it into basins formed by excavation or by the construction of containment dikes or small dams of dimensions varying from few meters to several hundred meters. The most common system consists of individual basins fed by pumped water from nearby surface water sources. Silt-free water avoids the problem of sealing basins during flooding. Basins require periodic scraping of the bottom surface when dry to preserve a percolation surface. Basins, because of their general feasibility and ease of maintenance, are the most favored method of artificial recharge from the surface. Gradients of major feeder ditches should be sufficient to carry suspended material through the system since deposition of fine grained material clogs soil surface openings. The primary purpose of water spreading is to extend the time and the area over which water is recharged. 


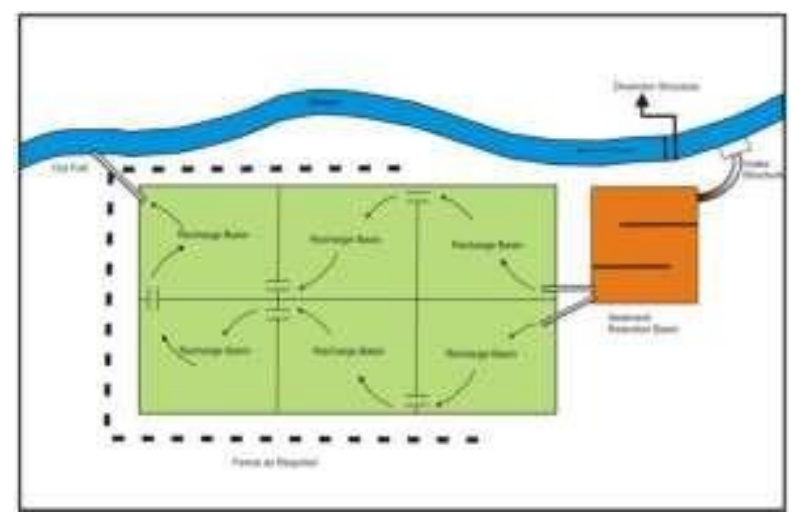

*DUG WELL RECHARGE.

*POND RECHARGE SHAFT.

\section{Ground Water Dams or Sub Surface Dykes}

A ground water dam is a sub-surface barrier across stream which retards the natural ground water flow of the system and stores water below ground surface to meet the Demands during the period of need. The main purpose of ground water dam is to arrest the flow of ground water out of the sub-basin and increase the

Storage within the aquifer. Water levels in upstream of ground water dam rises and saturating the otherwise dry part of aquifer. The underground dam has following advantages: -

Since the water is stored within the aquifer, submergence of land can be avoided and land above reservoir can be utilized even after the construction of the dam.

* No evaporation loss from the reservoir takes place.

* No siltation in the reservoir takes place.

* The potential disaster like collapse of dams can be avoided

\section{CONCLUSIONS-}

This paper discusses all the possible techniques which are being used to recharge ground water in India today, it has been noticed that to effectively eradicate this problem a continued and mutual effort from both government authorities and general public is needed. If the techniques highlighted are to be used they should be used by effectively all the prescribed guidelines.

\section{REFERENCES}

[1].Planning Commission, 2002, 10th Five Year Plan

[2].Planning Commission, 2000, midterm appraisal of 9th Five Year Plan

[3].World Bank, 1999, "Groundwater regulation and Management in India"

[4].Answers in Rajya Sabha, various dates

[5].Answers in Lok Sabha, various dates

[6].UNEP 2003, Groundwater its susceptibility to degradation

[7].Prof R Jagadishwara Rao, Oct 2003

[8].Govt of India, 1999, Report of the Commission on Integrated Water Resources Development

[9].World Commission on Dams, Nov 2000, Dams and Development: A framework for decision making

[10]. http://www.cgwaindia.com/

[11]. http://wrmin.nic.in/

[12]. International Assoc. of Hydrogeologists, http://www.silsoe.cranfield.ac.uk/iwe/projects/iahgroup/introduction.htm

[13]. Thakkar Himanshu, 1999. India Irrigation Options Study, done for World Commission on Dams, www.dams.org

[14]. strategies and policies for artificial recharge of ground water-Dr. S.K Sharma (ground water expert). 